\title{
A comparison of antioxidant capacity and some lipoprotein values in swimmers and sedentary subjects
}

\author{
ISMAIL GÖKHAN $\triangle$, YAKUP AKTAŞ, GÖKHAN ARIKAN \\ School of Physical Education and Sports, Harran University, Turkey
}

\begin{abstract}
Gökhan, I., Aktaş,Y. \& Arikan, G. (2014). A comparison of antioxidant capacity and some lipoprotein values in swimmers and sedentary subjects. J. Hum. Sport Exerc., 9(Proc1), pp.S490-S494. Increased oxygen consumption as a result of the exercise also increases the free radical production. These free radicals are neutralized by a defence mechanism consisting of enzymatic and non-enzymatic antioxidants. Training can have positive or negative effects on oxidative stress depending on the load and type of the training or the status of the individual prior to it. The purpose of this study is to search the capacity of lipoproteins, total oxidant and antioxidant in swimmers and sedentary subjects. The experimental group were 18 male children with mean age 15,16 0,92 who have been swimming at least for 2 years and exercise regularly 3 days a week and 2 hours a day, as the control group, 18 male children with mean age $15,33 \pm 1,08$ who do not regularly do any particular sports, participated voluntarily in our study. Oxidant-antioxidant measurements were conducted through venous blood samples collected in EDTA tubes on an empty stomach and at rest. Total Antioxidant Capacity (TAC) was determined through a method developed by Erel (2004) to measure the total antioxidant capacity of the body against the free radicals. Lipid Hydroperoxide $(\mathrm{LOOH})$ determination was specified with a method in which xylenol orange and Fe++ are used (Arab and Steghens, 2004). Total Oxidant Status (TOS) was determined through a colorimetric method developed by Erel (2004). Oxidative Stress Index (OSI) was calculated with the formula Total Oxidative Stress (TOS) / (TAC). Plasma triglyceride, Total cholesterol, LDL, HDL, VLDL parameters were measured using Abbot and automatic chemistry analyser (Aeroset, Abbott, USA). For the comparison of the experiment and the control groups, Independent Samples T-Test was applied to compare the independent groups on the SPSS 16.00 statistical package. Statistically significant difference was determined to be $p<0,05$. No statistically significant difference was observed between the body composition values of the experiment and the control groups $(p>0,05)$. Moreover, a statistically significant difference was observed between TAC, LOOH, TOS, OSI, TRIGLISERIT and HDL values of the experiment and the control groups $(p<0,05 ; p<0,01)$. No statistically significant difference was observed between both groups in terms of Cholesterol, LDL and VLDL values ( $p>0,05)$. It was concluded that total antioxidant and antioxidant capacity of the swimmers' group was higher compared to the sedentary group. The reason for this difference, we think, is that antioxidant defence mechanisms of the subjects who do swimming are more developed. Key words: SWIMMING, ANTIOXIDANT, LIPOPROTEIN, EXERCISE, OXIDATIVE STRESS.
\end{abstract}

Corresponding author. School of Physical Education and Sports, Harran University, Turkey.

E-mail: is_gokhan@hotmail.com.

8th INSHS International Christmas Sport Scientific Conference, 5-7 December 2013. International Network of Sport and Health Science. Szombathely, Hungary.

JOURNAL OF HUMAN SPORT \& EXERCISE ISSN 1988-5202

(c) Faculty of Education. University of Alicante

doi:10.14198/jhse.2014.9.Proc1.37 


\section{INTRODUCTION}

Oxidative stress is known as an instability between antioxidant defence system activated in the organism by physical activities performed and free radical formation which causes the pre-oxidation of the lipid layers of the cells (Mercan, 2004). Antioxidants function by terminating reactions which form free radicals, by limiting radical formation and detoxifying emerged radicals or enabling the repairment of the substances exposed to oxidative damage (Benzie, 2000). Free radicals which increase depending on the increase in oxygen consumption are neutralised by a defence system containing enzymatic and non-enzymatic antioxidants (Urso \& Clarkson, 2003). It is stated that acute exercises cause an increase in lipid preoxidation and regular exercises cause a positive change in the status of antioxidants. It is difficult to be protected against excessive oxidative stress in exercises conducted without a preparation. Studies show that programmed physical activities develop the status of the oxidants because of the chronic oxidative stress it causes, and thereby playing a role in the formation of a developed antioxidant mechanism (Aslan, 1997). The level of oxidant and the system of antioxidant defence system is balanced in a healthy body (Ersoy, 1996).

The purpose of this study is to compare some oxidative stress parameters of the individuals who swim.

\section{MATERIALS AND METHODOLOGY}

Selection of the Subjects: 18 male children with mean age 15,16 $\pm 0,92$ who have been swimming for at least 2 years and exercising regularly 3 days a week and 2 hours a day; as the control group 18 male children with mean age $15,33 \pm 1,08$ who do not regularly involve any sports activity participated voluntarily in the research.

Measurements Taken: Oxidant-antioxidant measurements were conducted through venous blood samples collected in EDTA tubes on an empty stomach and at rest. Antioxidant Capacity (TAC) was determined through a method developed by Erel to measure the total antioxidant capacity of the body against the free radicals (Arab \& Steghens, 2004). LOOH determination was specified with a method in which xylenol orange and $\mathrm{Fe}^{++}$are used (10). Total Oxidant Status (TOS) was determined through a colorimetric method developed by Erel (Erel, 2004). Oxidative Stress Index (OSI) was calculated with the formula Total Oxidative Stress (TOS) / Total Antioxidant Capacity (TAC) (Erel, 2004). Plasma triglyceride, Total cholesterol, LDL, HDL, VLDL parameters were measured using Abbot and automatic chemistry analyzer (Aeroset, Abbott, USA).

Statistical Analysis: For the comparison of the experiment and the control groups, SPSS 16.00 statistical package was used and Independent Samples T-Test was applied to compare the independent groups. Statistically significant difference was determined to be $p<0,05$.

\section{RESULTS}

Indentified values of the experiment group are like the following: TAC value: $1,93 \pm 0,23$, $\mathrm{LOOH}$ value: $4,67 \pm 0,55$ TOS values: $8,63 \pm 1,50$, OSI value: $7,84 \pm 1,51$, TRIGILISERIT value: $108,28 \pm 20,80$, HDL value: $53,22 \pm 9,07$. Determined values of the control group are like the following: TAC value: $1,76 \pm 0,13, \mathrm{LOOH}$ value: $4,13 \pm 0,77$, TOS value: $5,73 \pm 1,05$, OSI value: $5,30 \pm 1,18$, TRIGILISERIT value: $122,50 \pm 21,12$, HDL value: $46,88 \pm 7,88$. Statistically significant differences were observed between antioxidant and oxidative 
stress parameters of the experiment and control groups $(p<0,05)$. Besides, no statistically significant difference was observed between total cholesterol LDL and VLDL values $(p>0,05)$.

Table 1. Comparison of Antioxidant and Lipoprotein Parameters of the Experiment and Control Groups

\begin{tabular}{|c|c|c|c|c|}
\hline Variables & $\begin{array}{l}\text { Experiment } \\
\text { Group }\end{array}$ & Control Group & $t$ & $p$ \\
\hline Age & $15,16 \pm 0,92$ & $15,33 \pm 1,08$ & $-0,49$ & 0,62 \\
\hline Height & $168,33 \pm 6,60$ & $166,39 \pm 8,36$ & 0,77 & 0,44 \\
\hline Weight & $58,27 \pm 7,11$ & $57,00 \pm 7,66$ & 0,51 & 0,60 \\
\hline BMI & $20,50 \pm 1,67$ & $20,54 \pm 1,70$ & $-0,06$ & 0,94 \\
\hline Tac & $1,93 \pm 0,23$ & $1,76 \pm 0,13$ & 2,69 & $0,011^{*}$ \\
\hline Looh & $4,67 \pm 0,55$ & $4,13 \pm 0,77$ & 2,40 & $0,022^{*}$ \\
\hline Tos & $8,63 \pm 1,50$ & $5,73 \pm 1,05$ & 6,68 & $0,00^{* *}$ \\
\hline Osi & $7,84 \pm 1,51$ & $5,30 \pm 1,18$ & 5,60 & $0,00^{* *}$ \\
\hline Trigliserit & $108,28 \pm 20,80$ & $122,50 \pm 21,12$ & $-2,03$ & $0,05^{*}$ \\
\hline Kolestrol & $148,78 \pm 13,57$ & $152,44 \pm 15,29$ & $-0,76$ & 0,45 \\
\hline $\mathrm{Hdl}$ & $53,22 \pm 9,07$ & $46,88 \pm 7,88$ & 2,23 & $0,032^{*}$ \\
\hline Ldl & $92,33 \pm 24,01$ & $92,27 \pm 19,32$ & 0,008 & 0,994 \\
\hline vldl & $30,72 \pm 7,23$ & $33,83 \pm 6,92$ & $-1,31$ & 0,196 \\
\hline
\end{tabular}

\section{DISCUSSION AND CONCLUSIONS}

No statistically significant difference was observed between body composition values of the experiment and control groups ( $p>0,05)$. However, a statistically significant difference was observed between TAC, LOOH, TOS, OSI, TRIGLISERIT and HDL values of the experiment and the control groups $(p<0,05 ; p<0,01)$. No statistically significant difference was observed between both groups in terms of Cholesterol, LDL and VLDL values $(p>0,05)$.

Contrary to regular exercises, high intensity exercises with a maximum level increase the oxidative damage because of the increase in the formation of free radicals (Van Klaveren \& Nemery, 1999). The type of the exercise can be another factor which influences the lipid pre-oxidation. Greenen et al. (1993) stated in the research they conducted that the increase in the levels of lipid pre-oxidation in the studies conducted with a cycle ergonometric is higher than the increase determined in the swimming exercises (Geenen et al., 1993). In the research conducted on football players and sedentary individuals, Cazzalo et. al. stated that 
oxidative stress develops in football players more than it develops in sedentary and that antioxidant activities are higher compared to sedentary (Cazzalo, et al., 2003).

Ohno et al. (1988) stated that exercises reduce lipid pre-oxidation and lipid pre-oxidation level at rest is lower after a 3 weeks of exercise (Ohno et al., 1988). Gougoura et al. found that lipid pre-oxidation is higher in child swimmers compared to control groups (Gougoura et al., 2007). There are several studies in which statistically significant increases in MDA the last formation of lipid pre-oxidation are observed as a result of high intensity physical activities (Davies et al., 1982; Sumida et al., 1989).

When the data in literature is analyzed, the results of the studies conducted on this area show similarities with the results we obtained from our research.

As a result, antioxidant capacity and oxidative stress values were found to be higher in swimmers compared to sedentary. An increase in oxidative stress level due to exercise and an increase in the antioxidant capacity which the organism develops against this are expected results. We can propose that sportsmen could take additional antioxidant support.

\section{REFERENCES}

1. Arab, K. \& Steghens, J.P. (2004). Plasma lipid hydroperoxides measurement by an automated xylenol orange method. Anal Biochem, 325, pp.158-163.

2. Aslan, R. (1997). Sedanterlerde Akut ve Programlı Submaksimal Egzersizin Eritrosit Membram Lipit Peroksidasyonu ve Antioksidan Savunma Sistemi .zerine Etkilerinin Araştırılması, Yüzüncü Yıl .niversitesi Sağlık Bilimleri Enstit.s., Fizyoloji Anabilimdalı, Yayınlanmamış Doktora Tezi, Van, 1997.

3. Benzie, I. (2000). Evolution of antioxidant defence mechanisms. Eur J Nutr, 39, pp.53-61.

4. Cazzalo, R., Russo-Volpe, S., Cervato, G. \& Cestaro, B. (2003). Biochemical Assessments of Oxidative Stress, Erythrocyte Membrane Fluidity and Antioxidant Status in Professional Soccer Players and Sedentary Controls. Eur J Clin Invest, 33, pp.924-930.

5. Davies, K.J.A., Quintanilha, A.T., Brooks, G.A. \& Packer, L. (1982). Free Radicals and tissue damage produced by exercise. Biochem Biophys Res Commun, 107(4), pp.1196-1205.

6. Erel, O. (2004). A novel automated method to measure total antioxidant response against potent free radical reactions. J Clin Biochem, 37, pp.112-119.

7. Ersoy, G. (1996). Beslenme ve Egzersiz Hakkında Son Görüşler S.T.D ss.32-38.

8. Erythrocyte Activities of Free Radical Scavenging Enzyme Systems in Sedantery Men. J Appl Physiol, 57, pp.173-176.

9. Geenen, D., Buttnck, P \& Scheuer, J. (1993). Cardiovasculer and Hormonal Responses to Swimming and Running in the Rat. J Appl Physiol, 65, pp.116 123.

10. Gougoura, S., Nikolaidis, M.G., Kostaropoulos, I.A, Jamurtas, A.Z., Koukoulis G. \& Kouretas, D. (2007). Increased oxidative stress indices in the blood of child swimmers. Eur J Appl Physiol, 100, pp.235-239.

11. Mercan, U. (2004). Toksikolojide Serbest Radikallerin Önemi, Yüzüncü Yıl Üniversitesi, Veterinerlik Fakültesi Dergisi. 15 (1-2) Sayfa, pp.91-96.

12. Ohno, H., Yahata, T., Sato, Y., Yamamura, K. \& Tanuguchi, N. (1988). Physical training and fasting erythrocyte activities of free radical scavenging enzyme systems in sedentary men. Eur $J$ Appl Physiol Occup Physiol, 57(2), pp.173-6. 
13. Sumida, S., Tanaka, K., Kitao, H. \& Nakadomo, F. (1989). Exercise-induced lipid peroxidation and leakage of enzymes before and after Vitamin E supplementation. Int J Biochem, 21(8), pp.835-838.

14. Urso, M.L. \& Clarkson, P.M. (2003). Oxidative stress, exercise, and antioxidant. Supplementation Toxicology, 189, pp.41-54.

15. Van Klaveren, R.J. \& Nemery, B. (1999). Role of reactive oxygen species in occupational and environmental obstructive pulmonary, diseases. Current Opinion in Pulmonary Medicine, 5, pp.18123. 